Jacek PAŚ ${ }^{1}$, Sławomir BUCHLA

${ }^{1}$ Military University of Technology (Wojskowa Akademia Techniczna)

\title{
ANALYSIS OF THE ELECTRONIC DEVICE EXPLOITATION PROCESS - RESEARCH RESULTS
}

\section{Analiza procesu eksploatacji urządzenia elektronicznego - wyniki badań}

\begin{abstract}
The paper presents an analysis of the operation process of the selected electronic device (ED) like tablet type $X$. The damage of ED is caused by environmental exposure or use contrary to the applicable operating instructions. The damage initiates the process of changing many or one of the usable features of a specific ED. This usually leads to damage, i.e. changes in the properties of components of a specific ED (e.g. touch screen, compact systems, resistors, capacitors, battery cells, etc.). The basic operational indicators of the ED were determined based on the analysis of the type of damage to all devices that were reported to the service center - 2391 notifications. The research was carried out on the company's website, and the duration was 15 months from the time of the introduction of the ED to the market.
\end{abstract}

Keywords: damage, warranty repair, average repair time

Streszczenie: Przedstawiono analize procesu eksploatacji wybranego urzadzenia elektronicznego (ue) typu tablet firmy X. Uszkodzenie ue powstaje pod wptywem narażenia środowiskowego lub użtkowania niezgodnie z obowiazujaca instrukcja eksploatacji. Uszkodzenie inicjuje proces zmiany wielu lub jednej cechy użytkowej danego ue. Prowadzi to zwykle do uszkodzenia, tj. zmiany właściwości elementów składowych danego ue (np. ekran dotykowy, układy scalone, rezystory, kondensatory, baterii akumulatorów, itd.). Podstawowe wskaźniki eksploatacyjne ue zostały wyznaczone w oparciu o analize rodzaju uszkodzeń wszystkich urządzeń które zostały zgłoszone do punktu serwisowego - 2391 zgłoszeń. Badania zostaty przeprowadzone w serwisie firmy, a czas trwania wynosit 15 miesięcy od chwili wprowadzenia ue na rynek.

Słowa kluczowe: uszkodzenie, naprawa gwarancyjna, średni czas naprawy 


\section{Selected characteristics and reliability indicators}

The analysis of the operation process of the selected ED was carried out from 02. 2015 to 04. 2016. The total number of reported repairs concluded in this period in the catalog data collected on the site was 2391 . All repairs were registered in the service system. The number of general repairs also includes secondary repairs (socalled returns). These are repairs that have the same registration number and a few dates of submission in the catalog's catalog card. Secondary repairs, so-called the ED's return to the website was connected with damage to another item, the ED system that was found during the collection or subsequent short operation by the user. The beginning of the analyzed service time coincides with the commencement of ED sales $[1,5,14]$. The data on ED damage found in the datasheets has not been updated. The final ED order for the manufacturer was submitted in 2014 - in an amount of 10,000 pieces. The whole production, along with the ordering of the necessary parts and assembly, took the supplier about a month. ED transport by sea lasted about two months. At the end of January 2015, the ED was in the company's warehouse. The company distributed the ED to points of sale. Repairs that occurred at the $\mathrm{X}$ service center can be divided into:

- warranty - free repairs carried out under the guarantee contract,

- pre-sale - repair of goods in which the defect was detected in the store,

- paid - repairs in which the defect was created is not covered by the guarantee,

- conditional - repairs that are made at the service cost due to special circumstances, e.g. damage found during land or sea transport - fig. 1,

- other - a special category, which includes, among others, repairs made by other companies, including foreign ones. These repairs generate high costs.

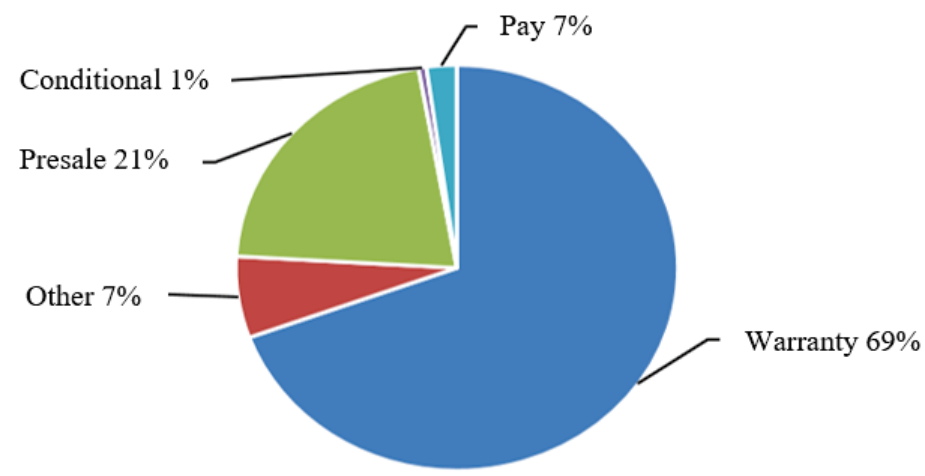

Fig. 1. Types of repairs due to the commitment of the selling company 
The term returns is called secondary repairs in which after repair and the same defect was revealed again to the customer or the user stated another defect and returned ED again for repair. Fig. 2 shows the percentage of returns in the total number of repairs with the distinction for multiple returns. The returns shown in fig. 2 mean respectively:

- 2 - returns means that the ED has been registered twice on the website within one month,

- 3 - returns means that the ED has been registered three times in one month,

- 4 - returns means that the ED has been registered four times in one month.
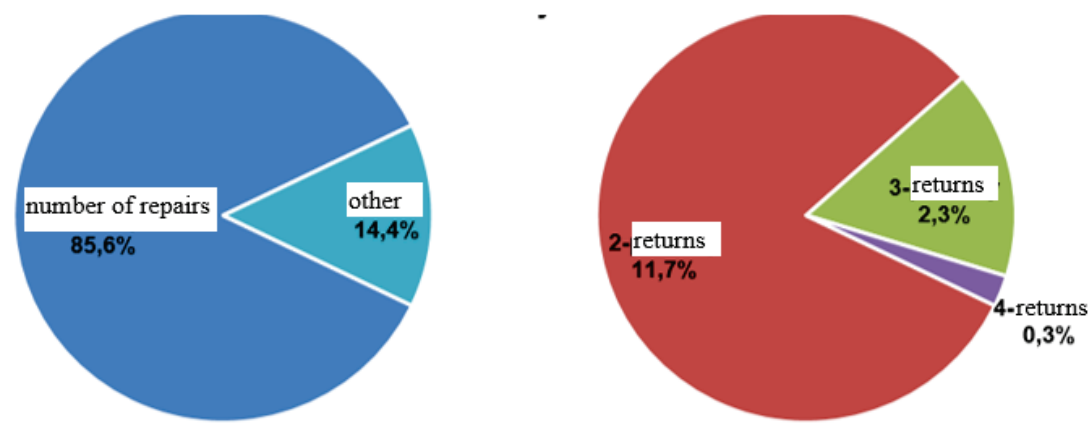

Fig. 2. Percentage of returns in the general set of repairs occurring at the service point

\section{Average repair time}

The most important parameter of a service point is the average repair time of a given ED. Figures 3-6 show charts that refer to the total number of repairs in relation to the average repair time. The charts have been divided into the type of commitment that occurs on the ED seller's side. As the basic unit of time at which the service point can perform the repair was taken 24 hours. This means that the shortest time for completing a single repair is one day. This time is counted from the moment of registration to the receipt of the repaired ED by the customer. Each registered repair in the system receives a time buffer of 14 business days (each day following registration, one day from the buffer is subtracted). The repair time carried out in accordance with the ED return regulations should include only positive values in the buffer. If the repair time exceeded 14 days, the excess buffer in the buffer took negative values (if the time of repair completed in the buffer was - 4 days, the total repair time was exceeded by 4 business days). The charts show the average repair time. It is calculated according to the arithmetic mean of repair 
times in a given calendar month. If the value of this time in the chart is negative, it means exceeding the set 14-day time. Positive values mean that most of the repairs were completed within a given period. The average repair time is also influenced by factors such as the availability of spare parts, the so-called service capacity, experience of service technicians, logistics (i.e. delivery of spare parts), equipment with diagnostic tools, etc. The average repair time takes negative values between February and July - fig. 3. This is the result of the lack of spare parts and the lack of qualifications of service employees in the repairs of the new ED. Since August 2015, the situation has been dramatically improved - fig. 3. Repair times assumed only positive values, with the simultaneous increase in the volume of registered reported damage to the $\mathrm{ED}[11,13,16,18]$. This is mainly due to two conditions: access to spare parts for a given ED (a handy spare parts warehouse has been created on the website), and the experience of employees has increased over time. For the case of warranty repairs - fig. 4, negative times were recorded only at the beginning of the test period.

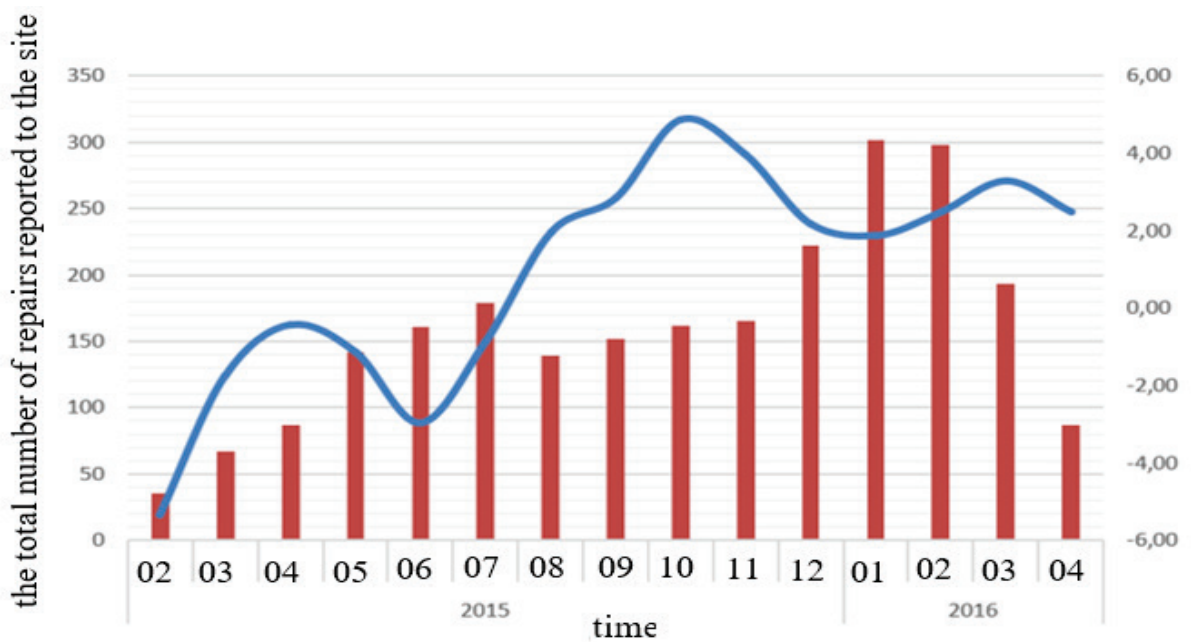

Fig. 3. All types of repairs reported to the service center. The average ED repair time specified in days

The maximum repair time by the service was reached in June. About $44 \%$ of repairs from this period of time were not completed within the set deadline. An important reason for increasing the repair time is the beginning of the holiday season. Since July 2015, the time of ED repair has gradually improved, and in 2016 the average value was only 2.84 working days. This value was maintained until the end of the research period. In the case of pre-sale repairs, the repair time is not the 
most important factor that determines the operation of the service point. For repairs of this type, the most important is the completion of the repair within 14 days fig. 5. This is due to the following situation, the customer did not buy the device due to the disclosure of the defect in the store $[3,6,8,17]$. The manufacturer accepted the equipment from the seller as a return of goods. After the repair, the devices were registered as second-class goods. Then, these ED's are sold at a lower price in one of the auction sites as exhibition goods or after service items. Paid repairs are characterized by low volume and long repairs - fig. 6 .

The priority for the company's service is always warranty repairs. Spare parts available are primarily assigned warranty obligations - they have the highest priority. In addition, paid repairs are not subject to rigorous legal restrictions. The manufacturer imposes a relatively high cost of repair payable in relation to the price of the device - which discourages the customer to perform this type of repair. Repair can be settled as unrepaired due to lack of parts without negative consequences for the manufacturer $[7,9,12,17]$. A long repair time is in this case dictated by the lack of spare parts or problems with their availability on the Polish market. The costs of such repairs in most cases are borne by the customer.

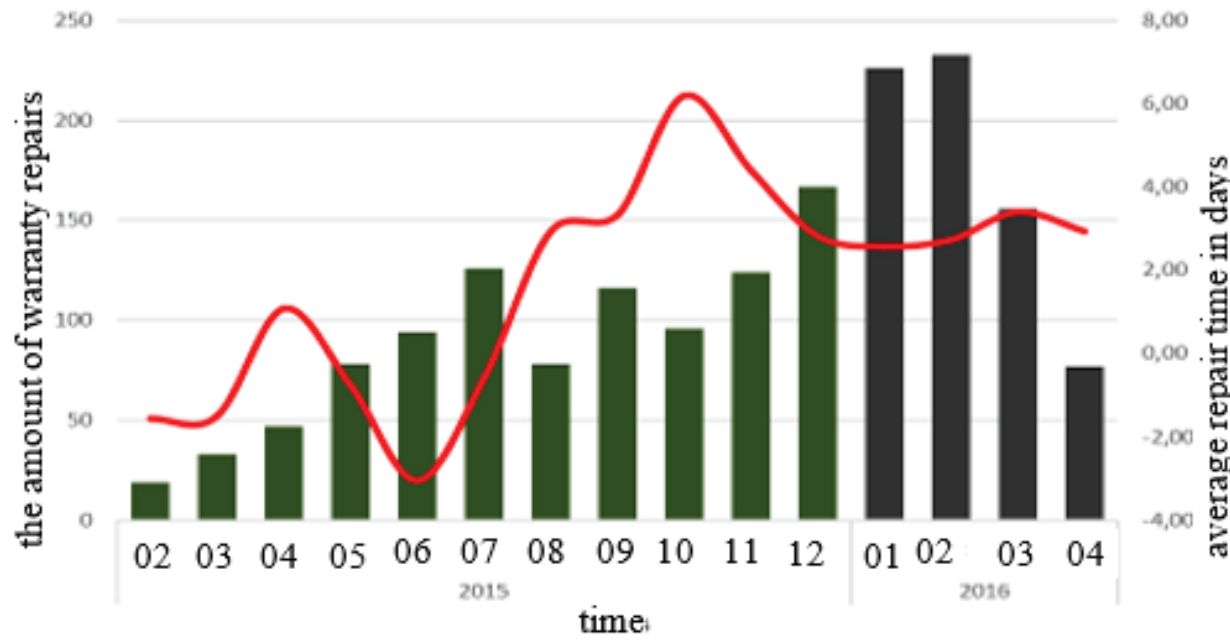

Fig. 4. The number of damage reported and the average warranty repair time 


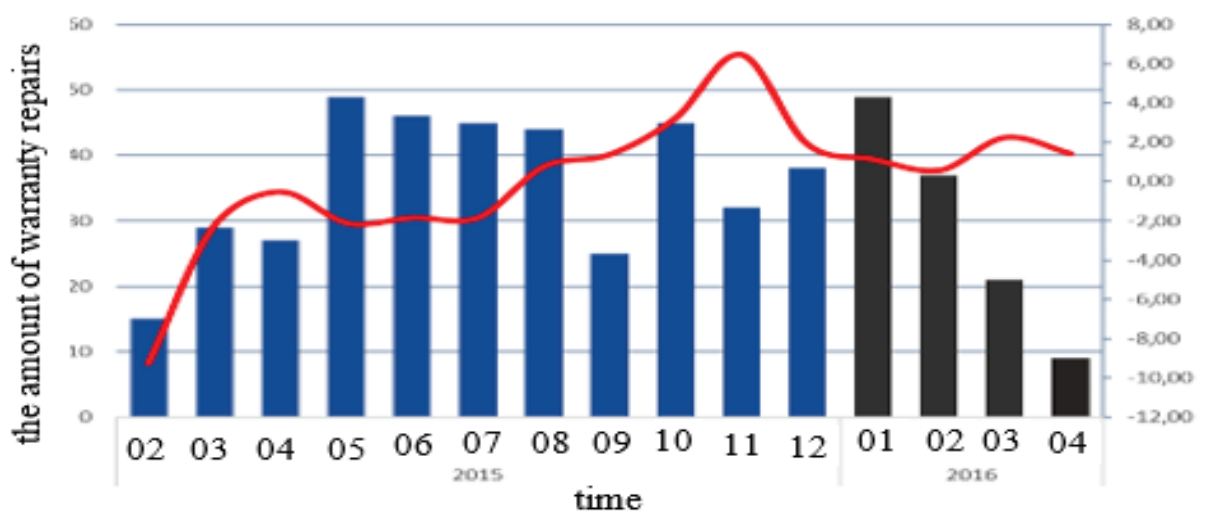

Fig. 5. The number of damage reported and the average pre-sale repair time

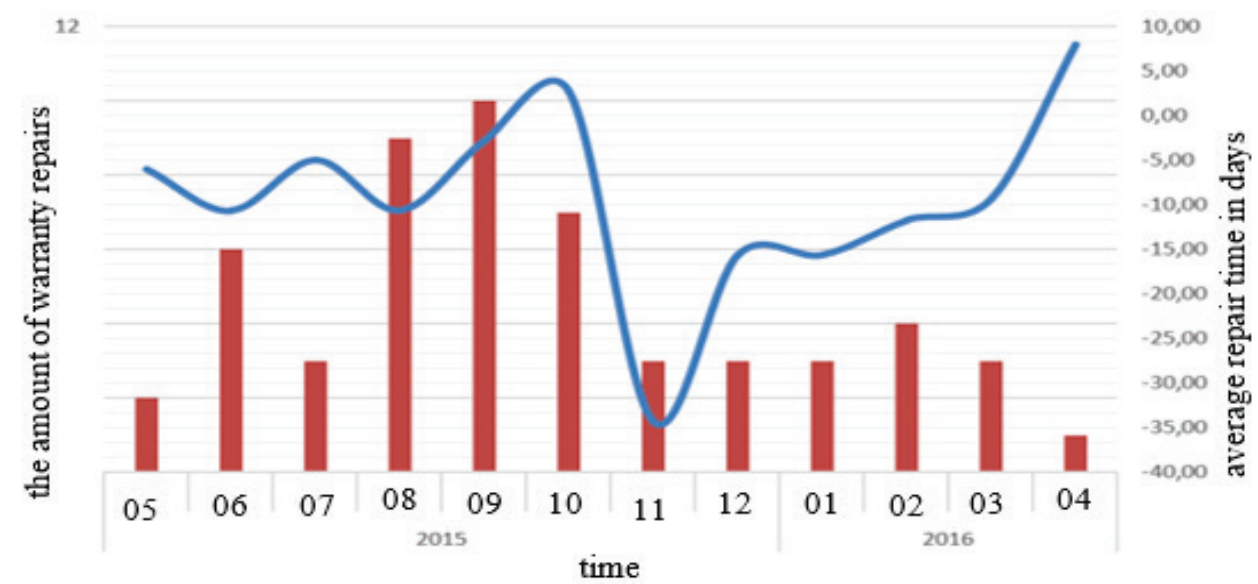

Fig. 6. The number of reported damages and the average time carried out for a fee

\section{Indicators of reliability of an electronic device}

Reliability indicators were determined for the three most common ED failures (figs. 7-12), i.e .:

- damage to the battery supplying the device,

- damage to the SIM card module or incorrect operation of the GSM module,

- damage to the touch panel.

Failure reliability ratios for the above mentioned damage were determined. The following distributions can be included in the following reliability indicators:

- intensity of damage $\lambda$ (ti) - figs. $8,10,12$, 
- the probability of the reliability of R (ti) - figs. 7, 9, 11,

- the likelihood of damage Q (ti).

All the graphs shown below (figs 7-12) were made using the division of the time axis into particular months of service point operation. Only business days were considered when analyzing the type of damage.

The service did not work on public holidays. In the damage registers of a given $\mathrm{ED}$, all damages which concerned a given device were taken into account, and appeared in the service point within the time period in which the analysis was carried out, i.e. 15 months (February 2015 to April 2016). The selected period of observation was characterized by the highest frequency of damage. This result is directly linked to the start of the ED sales in large format stores.

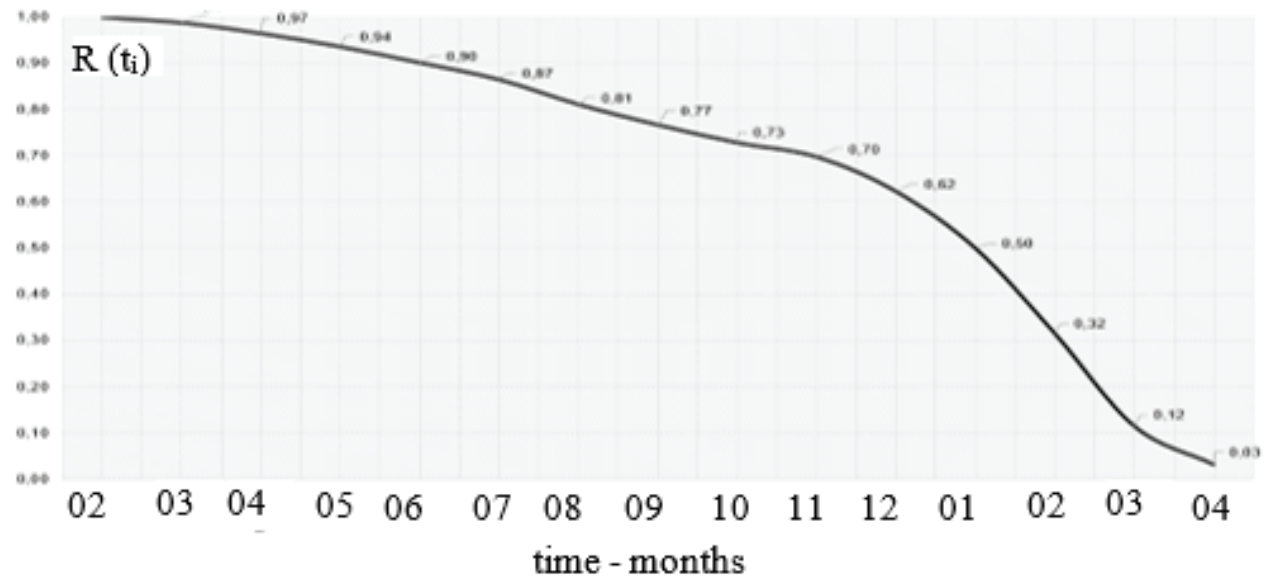

Fig. 7. The probability of the reliability of the $R\left(t_{i}\right)$ of the power supply battery

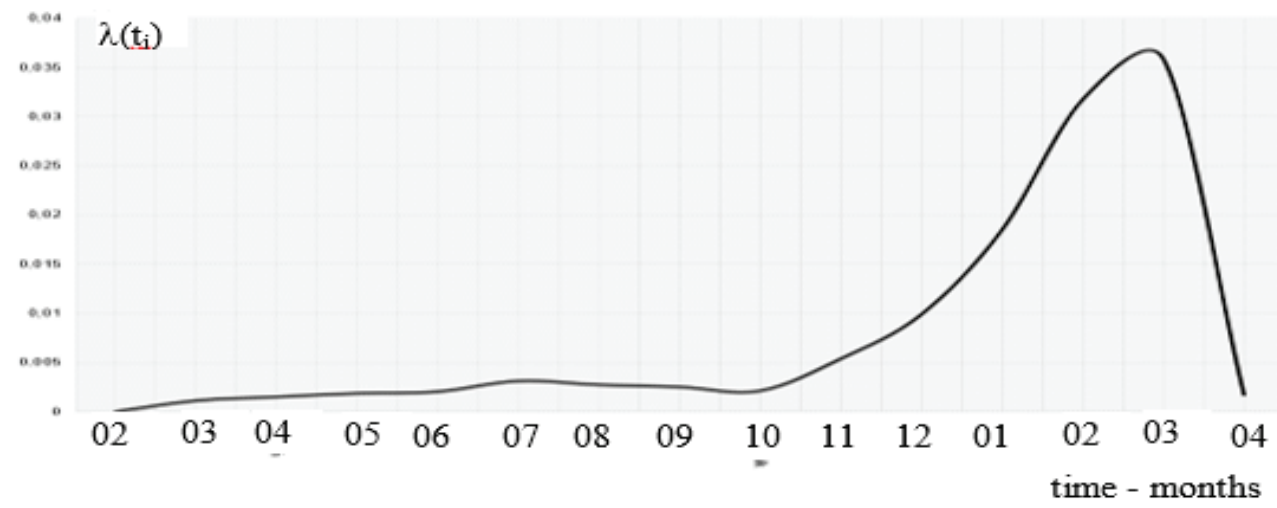

Fig. 8. Intensity of $\lambda(t)$ damage to the battery 


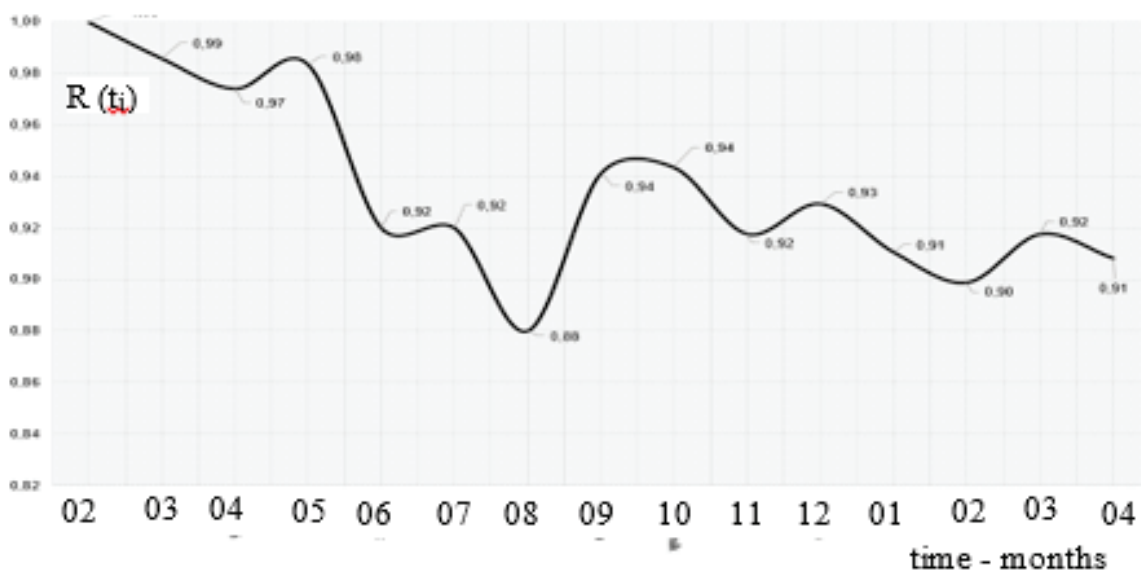

Fig. 9. The probability of the reliability of the $\mathrm{R}\left(\mathrm{t}_{\mathrm{i}}\right)$ of the SIM card

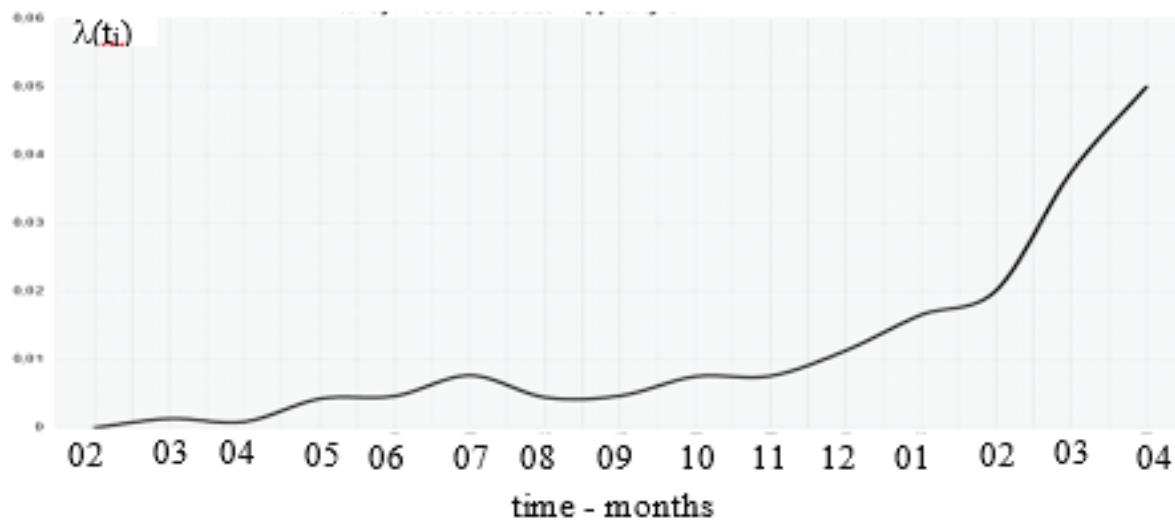

Fig. 10. Intensity of $\lambda(t)$ damage to the SIM card

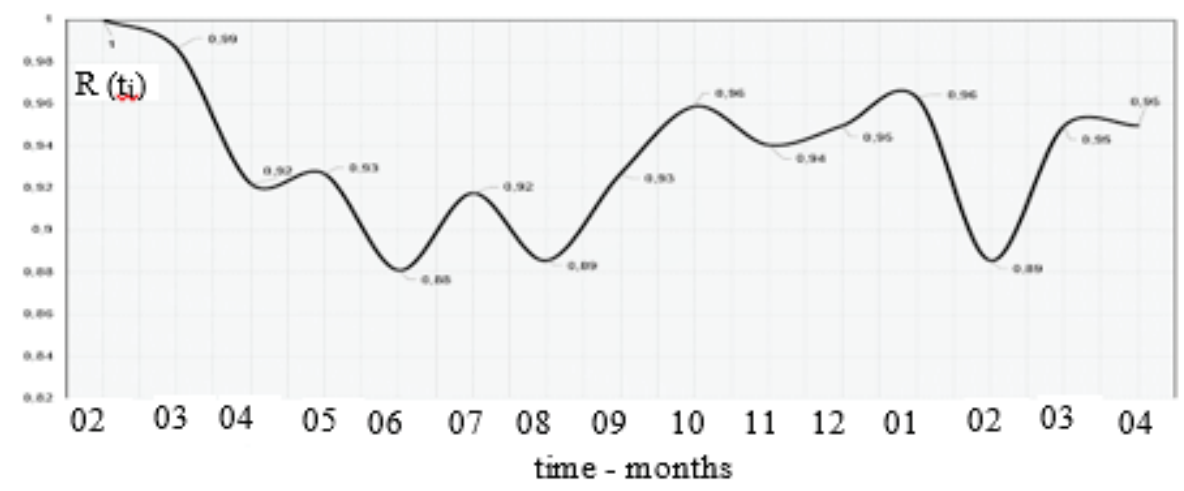

Fig. 11. Probability of the reliability of the $R\left(t_{i}\right)$ touch panel 


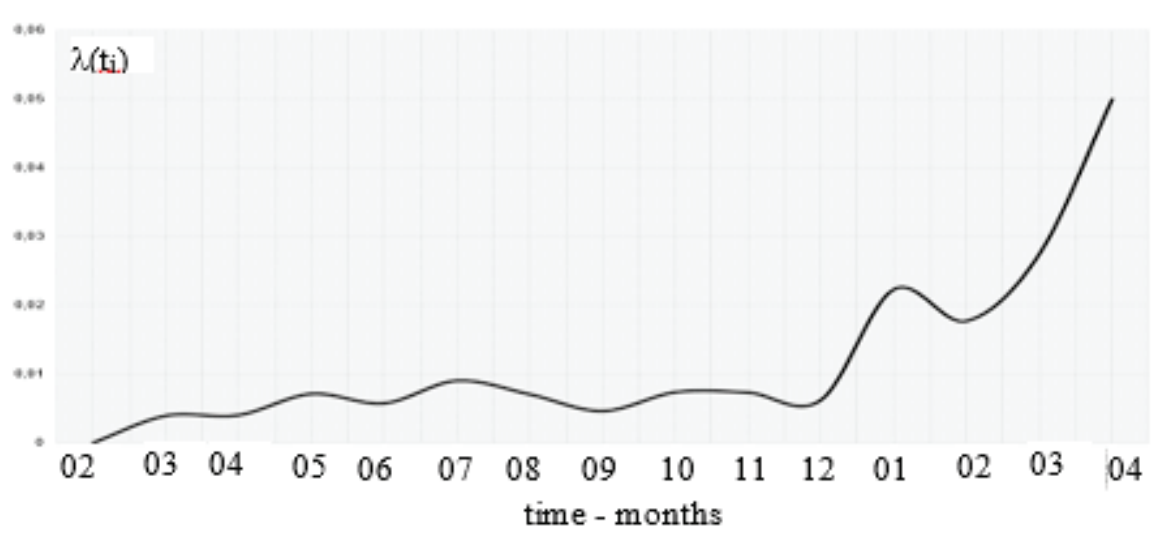

Fig. 12. Intensity of $\lambda(t)$ of the touch panel damage

\section{Conclusions}

The intensity of damage to individual components of the ED is different. The highest intensity of damages for the power supply batteries occurred in the months of February - March. These are the winter months when the temperatures prevailing outside and inside the warehouse, they were smaller than those for the storage of this type of ED. The process of damage to the ED battery has already started during the transport of equipment to the country (maritime transport). In addition, there was a smaller battery capacity than declared by the manufacturer. ED batteries should be recharged as soon as they arrive in the warehouse. Charging of the battery was not performed due to limited space conditions and time $[2,4,5,11,10,15]$. The customer received the EDwith a discharged battery. After charging the battery for 3 hours the ED worked about half an hour or it did not start. The situation improved significantly when the service began replacing the batteries with new ones. The usability of the SIM card (message on the ED panel) was mainly caused by two different damages. Incorrect marking of the ED connector, effect - incorrect positioning of the SIM card. Second type of software (software) damage. The ED producer reacted too late to the software defect and, at the same time, the company's software could not be updated. The software defect affected every ED. Damage to the touch panel was mainly caused by its faulty execution. Most often this was manifested by the lack of reaction to the touch of the screen. The biggest increase in the likelihood of touch panel damage was noted in the summer months (during this time the tablet was most actively used - need to use the Internet). Only service provided by highly qualified staff and adaptation of the logistics system of the 
service to effective repairs is crucial in building customer satisfaction and sales agent confidence through the sale of their goods in large format stores.

\section{References}

1. Będkowski L., Dąbrowski T.: Podstawy eksploatacji, cz. II Podstawy niezawodności eksploatacyjnej. WAT, Warszawa 2006.

2. Burdzik R., Konieczny Ł., Figlus T.: Concept of on-board comfort vibration monitoring system for vehicles. In: J. Mikulski (ed.), Activities of Transport Telematics, TST 2013, Springer, Heidelberg 2013.

3. Dyduch J., Paś, J., Rosiński A.: Basics of maintaining electronic transport systems. Publishing House of Radom University of Technology, Radom 2011.

4. Kaniewski P., Lesnik C., Susek W., Serafin P.: Airborne radar terrain imaging system. In 16th International Radar Symposium (IRS), Dresden 2015.

5. Kołowrocki K., Soszyńska-Budny J.: Reliability and safety of complex technical systems and processes. Springer, London 2011.

6. Laskowski D., Łubkowski P., Pawlak E., Stańczyk P.: Anthropotechnical systems reliability. In: „Safety and Reliability: Methodology and Applications - Proceedings of the European Safety and Reliability Conference ESREL 2014”, eds. Nowakowski T., Młyńczak M., Jodejko-Pietruczuk A., Werbińska-Wojciechowska S., CRC Press/Balkema, London 2015.

7. Lewiński A., Perzyński T., Toruń A.: The analysis of open transmission standards in railway control and management. In Communications in Computer and Information Science, Vol. 329, Springer-Verlag, Berlin-Heidelberg 2012.

8. Paś J., Dąbrowski T.: Metodyka nauczania diagnozowania systemów bezpieczeństwa na przykładzie systemów sygnalizacji włamania i pożaru. Diagnostyka, PTDT, Nr 2(46)/ 2008.

9. Paś J., Rosiński A.: Selected issues regarding the reliability-operational assessment of electronic transport systems with regard to electromagnetic interference. Eksploatacja i Niezawodność - Maintenance and Reliability, Vol. 19, No. 3, 2017 I, DOI 10.17531/ein.2017.3.8.

10. Paś J.: Analysis of exploitation access control system selected object. Przegląd Elektrotechniczny, No. 10, 2015.

11. Paś J.: Operation of electronic transportation systems. Publishing House University of Technology and Humanities, Radom 2015.

12. Paś J.: Selected methods for increases reliability the of electronic systems security, Journal of KONBiN, 3(35), 2015, DOI 10.1515/jok-2015-047.

13. Paszkowski S.: Podstawy teorii systemów i analizy systemowej. WAT, Warszawa 2002.

14. Rosiński A.: Modelowanie procesu eksploatacji systemów telematyki transportu. Oficyna Wydawnicza Politechniki Warszawskiej, Warszawa 2015. 
15. Siergiejczyk M., Paś J., Rosiński A.: Issue of reliability-exploitation evaluation of electronic transport systems used in the railway environment with consideration of electromagnetic interference. IET Intelligent Transport Systems, Vol. 10, Iss. 9, November 2016, DOI 10.1049/iet-its.2015.0183.

16. Siergiejczyk M., Paś J., Rosiński A.: Train call recorder and electromagnetic interference. Diagnostyka, Vol. 16, No. 1, 2015.

17. Siergiejczyk M., Rosiński A., Paś J.: Analysis of unintended electromagnetic fields generated by safety system control panels. Diagnostyka, Vol. 17, No. 3, 2016.

18. Żółtowski B.: Reliability engineering guide. ATR, Bydgoszcz 2002. 


\section{ANALIZA PROCESU EKSPLOATACJI URZĄDZENIA ELEKTRONICZNEGO - WYNIKI BADAŃ}

\section{Wybrane charakterystyki i wskaźniki niezawodnościowe}

Analize procesu eksploatacji wybranego ue przeprowadzono w okresie od lutego 2015 r. do kwietnia 2016 r. Łączna liczba zgłoszonych napraw zawartych w tym okresie w danych katalogowych w serwisie wynosiła 2 391. Wszystkie naprawy zostały zarejestrowane w systemie serwisowym - karcie katalogowej. W liczbie ogólnej napraw znajdują się także naprawy wtórne (tzw. powroty). Są to naprawy, które posiadają ten sam numer rejestracji oraz kilka terminów zgłoszenia w karcie katalogowej serwisu. Naprawa wtórna, tzw. powrót ue do serwisu, związana była $\mathrm{z}$ uszkodzeniem innego elementu czy układu, które zostało stwierdzone podczas odbioru z serwisu lub późniejszej krótkiej eksploatacji przez użytkownika. Początek analizowanego czasu pracy serwisu zbiega się $z$ rozpoczęciem sprzedaży ue $[1,5,14]$. Danych dotyczących uszkodzeń ue umieszczonych $\mathrm{w}$ kartach katalogowych nie poddawano aktualizacji. Finalne zamówienie na ue u producenta w kraju złożono w 2014 r. w liczbie 10000 sztuk. Całość produkcji wraz z zamówieniem potrzebnych części i montażem zajęła dostawcy ok. miesiąca. Transport drogą morską trwał ok. dwóch miesięcy. Pod koniec stycznia 2015 r. urządzenia były w magazynie firmy. Firma dystrybuowała je do punktów sprzedaży. Naprawy, które wystapiły w punkcie serwisowym firmy $\mathrm{X}$, można podzielić na:

- gwarancyjne - naprawy bezpłatne wykonywane w ramach umowy gwarancyjnej,

- przedsprzedażowe - naprawy towaru, w którym usterkę wykryto w sklepie,

- płatne - naprawy, w których powstała usterka nie jest objęta gwarancjac,

- warunkowe - naprawy, które są wykonane na koszt serwisu ze względu na specjalne okoliczności, na przykład stwierdzone uszkodzenia w czasie transportu lądowego lub morskiego - rys. 1,

- inne - kategoria specjalna, która zawiera m.in. naprawy wykonane przez inne firmy, w tym zagraniczne. Naprawy te generują duże koszty. 


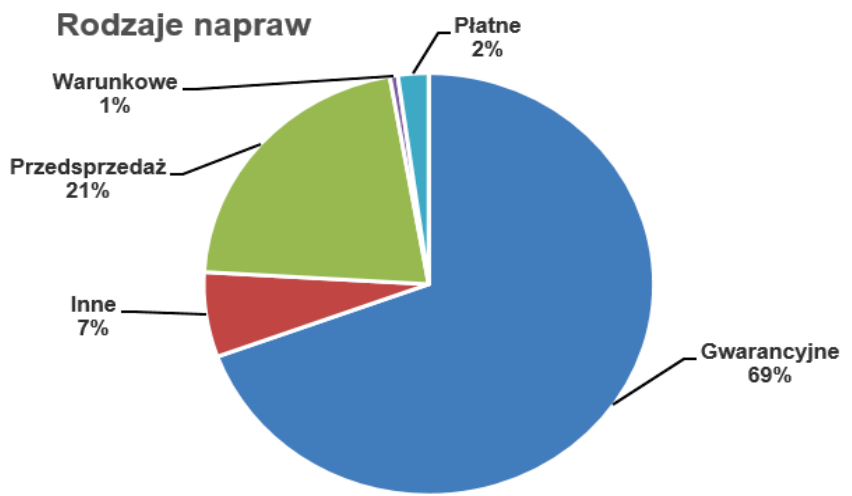

Rys. 1. Rodzaje napraw ze względu na zobowiązanie występujące po stronie firmy sprzedającej

Na rys. 2 przedstawiono procentowy udział napraw wtórnych w ogólnej liczbie napraw z rozróżnieniem na powroty wielokrotne. Powroty przedstawione na rys. 2 oznaczają odpowiednio:

- 2-powroty - ue dwukrotnie zarejestrowano w serwisie w ciagu jednego miesiąca,

- 3-powroty - ue zostało zarejestrowane trzy razy w ciagu jednego miesiąca,

- 4-powroty - ue zarejestrowano czterokrotnie w ciagu jednego miesiąca.
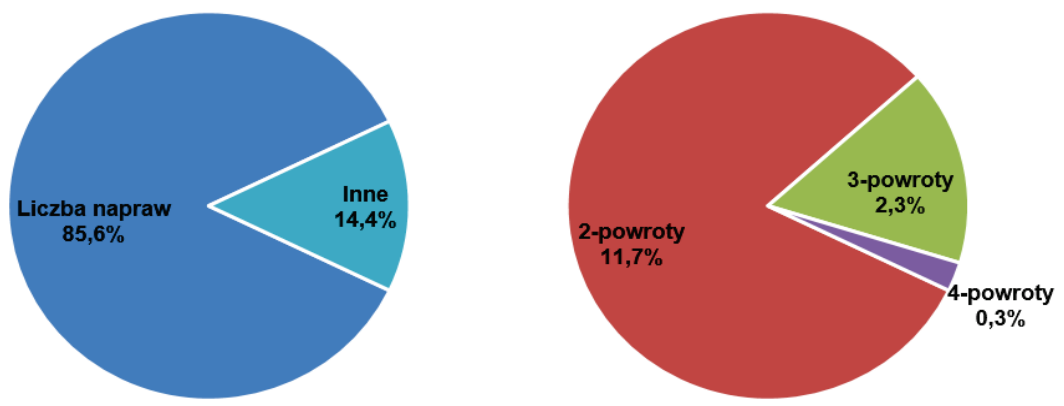

Rys. 2. Procentowy udział powrotów w ogólnym zestawie napraw występujących w punkcie serwisowym

\section{2. Średni czas naprawy}

Najważniejszym parametrem charakteryzującym punkt serwisowy jest średni czas naprawy danego urządzenia. Na rys. 3-6 przedstawiono łączną liczbę napraw 
w stosunku do średniego czasu naprawy. Wykresy zostały podzielone na rodzaj zobowiązania, które występuje po stronie sprzedawcy. Jako podstawową jednostkę czasu, w którym punkt serwisowy może wykonać naprawę, przyjęto $24 \mathrm{~h}$. To oznacza, że najkrótszy czas realizacji pojedynczej naprawy wynosi jeden dzień. Czas ten liczony jest od momentu rejestracji do momentu odbioru naprawionego urządzenia przez klienta. Każda zarejestrowana naprawa w systemie otrzymuje bufor czasowy 14 dni roboczych (każdego następnego dnia od rejestracji, odejmowany jest jeden dzień z buforu). Czas naprawy realizowany zgodnie $\mathrm{z}$ regulaminem zwrotu ue do serwisu powinien zawierać w buforze tylko wartości dodatnie. Jeżeli czas naprawy przekraczał 14 dni to w buforze nadmiarowe dni przyjmowały wartości ujemne (jeżeli czas zakończonej naprawy w buforze wyniósł -4 dni, to czas całkowitej naprawy został przekroczony o 4 dni robocze). Na wykresach przedstawiono średni czas naprawy. Wyliczany jest on według średniej arytmetycznej czasów napraw w danym miesiącu kalendarzowym. Jeżeli wartość tego czasu na wykresie jest ujemna, oznacza przekroczenie ustalonego 14-dniowego czasu. Wartości dodatnie oznaczają, iż w danym okresie większość napraw została zakończona w terminie. Na średni czas naprawy wpływ mają także takie czynniki jak: dostępność części zapasowych, tzw. moce przerobowe serwisu, doświadczenie serwisantów, logistyka (tj. dostawa części zamiennych), wyposażenie w przyrządy diagnostyczne, itd. [11, 13, 16, 18].

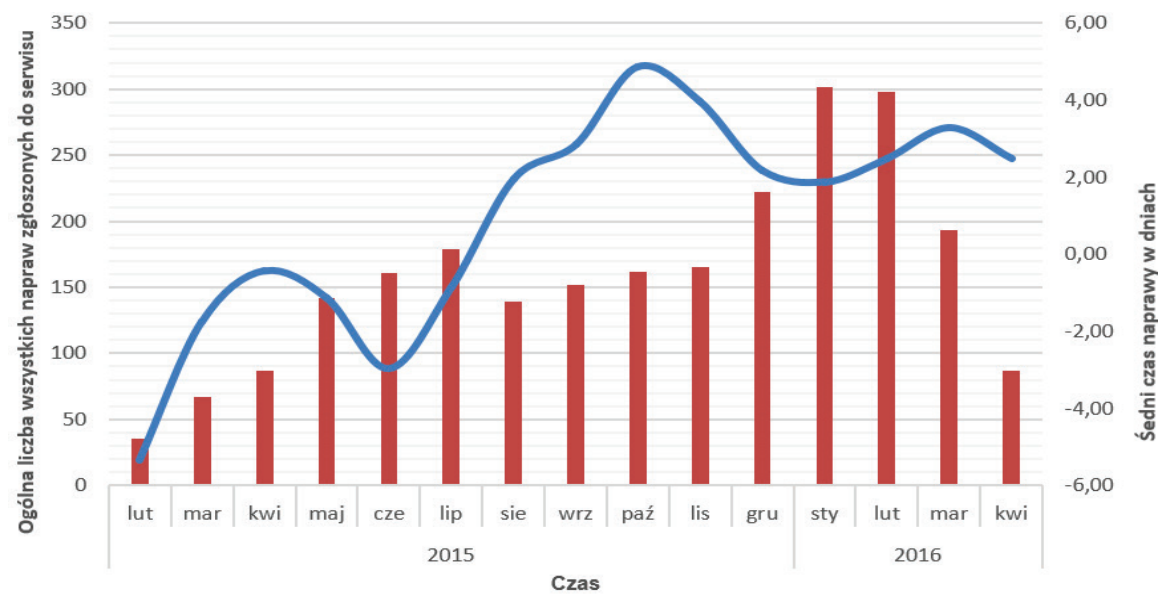

Rys. 3. Wszystkie rodzaje naprawy zgłoszone do punktu serwisowego. Średni czas naprawy ue określony w dniach

Średni czas naprawy przyjmuje ujemne wartości między lutym a lipcem rys. 3. Jest to wynikiem braku części zapasowych oraz brakiem kwalifikacji 
pracowników serwisu w naprawach nowego ue. Od sierpnia 2015 r. sytuacja uległa diametralnej poprawie - rys. 3. Czas napraw przyjmował wartości tylko dodatnie, przy jednoczesnym wzroście wolumenu zarejestrowanych - zgłoszonych ue. Wynika to z głównie $\mathrm{z}$ dwóch warunków: dostęp do części zapasowych danego urządzenia (utworzono podręczny magazyn części zapasowych w serwisie), a także zwiększyło się z czasem doświadczenie pracowników. Dla przypadku napraw gwarancyjnych (rys. 4) ujemne czasy zarejestrowano tylko na początku okresu badań. Maksymalny czas naprawy przez serwis został osiagnięty w czerwcu. Około $44 \%$ napraw $\mathrm{z}$ tego okresu nie została ukończona w ustalonym terminie. Istotnym powodem zwiększenia czasu naprawy jest początek sezonu urlopowego. Od lipca 2015 r. czas naprawy stopniowo ulegał poprawie, a w 2016 r. wartość średnia wynosiła tylko 2,84 dnia roboczego. Wartość ta utrzymała się do końca okresu badań.

W przypadku napraw przedsprzedażowych czas naprawy nie jest najistotniejszym czynnikiem, który decyduje o pracy punktu serwisowego $[3,6,8,17]$. Dla napraw tego typu najważniejsze jest zakończenie naprawy w ciagu $14 \mathrm{dni}-$ rys. 5. Wynika to z sytuacji, że klient nie kupił urządzenia z powodu ujawnienia usterki w już sklepie. Producent przyjął urządzenia od sprzedawcy jako zwrot towaru. Po naprawie urządzenia zostały zarejestrowane jako towar drugiej kategorii $[7,9,12,17]$. Następnie te są one sprzedane w niższej cenie w jednym z serwisów aukcyjnych jako towary powystawowe lub poserwisowe. Naprawy płatne charakteryzują się małym wolumenem oraz długim czasem napraw - rys. 6 .

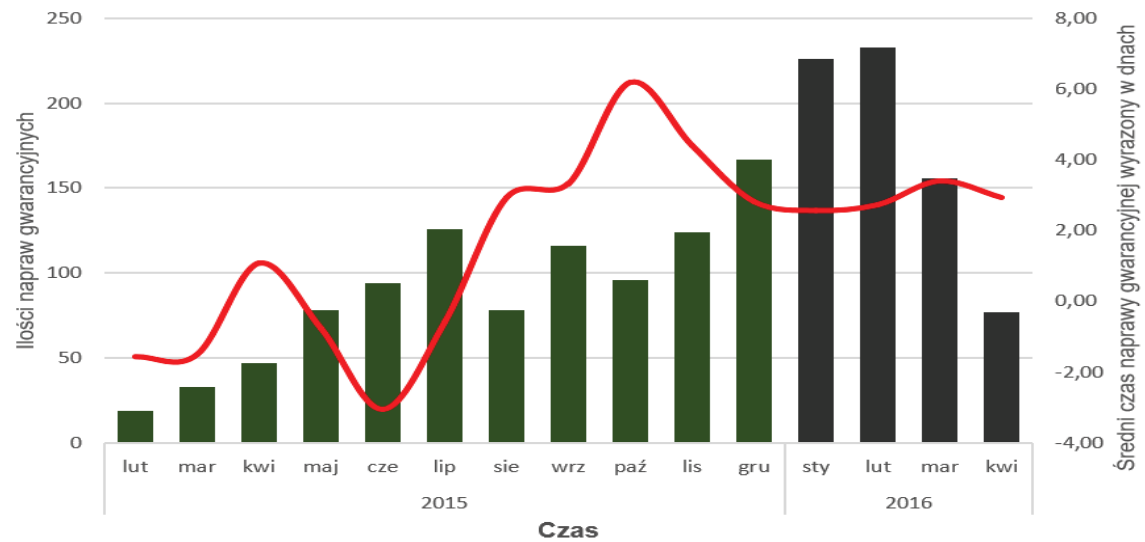

Rys. 4. Liczba zgłoszonych uszkodzeń i średni czas naprawy gwarancyjnej 


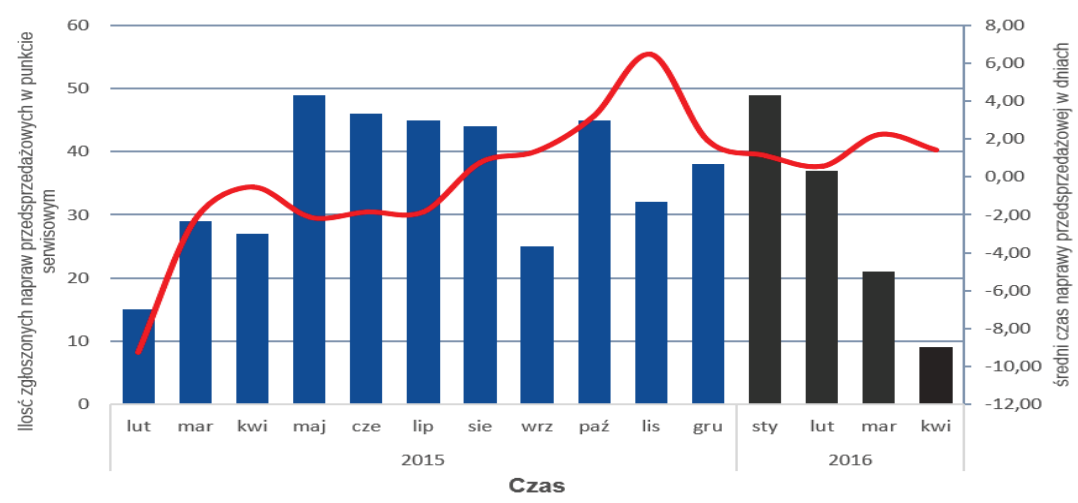

Rys. 5. Liczba zgłoszonych uszkodzeń i średni czas naprawy przedsprzedażowej

Priorytetem dla serwisu firmy są zawsze naprawy gwarancyjne. Dostępne części zapasowe są przydzielane przede wszystkim zobowiązaniom gwarancyjnym - maja największy priorytet. Dodatkowo naprawy płatne nie podlegają rygorystycznym obostrzeniom prawnym. Producent narzuca relatywnie duże koszty naprawy płatnej w stosunku do ceny urządzenia, co zniechęca klienta do wykonania tego typu naprawy. Naprawa może być rozliczona jako nienaprawiona z powodu braku części bez negatywnych konsekwencji dla producenta. Długi czas naprawy $\mathrm{w}$ tym przypadku podyktowany jest brakiem części zamiennych lub problemami z ich dostępnością na polskim rynku. Koszty logistyczne takiej naprawy w większości przypadków ponosi klient.

\section{Wskaźniki niezawodności urządzenia elektronicznego}

Wyznaczano wskaźniki niezawodności dla trzech najczęściej występujących uszkodzeń ue (rys. 7-12), tj.:

- uszkodzenie baterii zasilającej urządzenie,

- uszkodzenie modułu karty SIM lub nieprawidłowa praca modułu GSM,

- uszkodzenie panelu dotykowego.

Wyznaczono wskaźniki niezawodności uszkodzeń dla tych uszkodzeń. Do wyznaczonych wskaźników niezawodności można zaliczyć następujące rozkłady:

- intensywność uszkodzeń $\lambda$ (ti) - rys. $8,10,12$,

- prawdopodobieństwo nieuszkadzalności R(ti) - rys. 7, 9, 11,

- prawdopodobieństwo uszkadzalności $Q\left(t_{i}\right)$. 


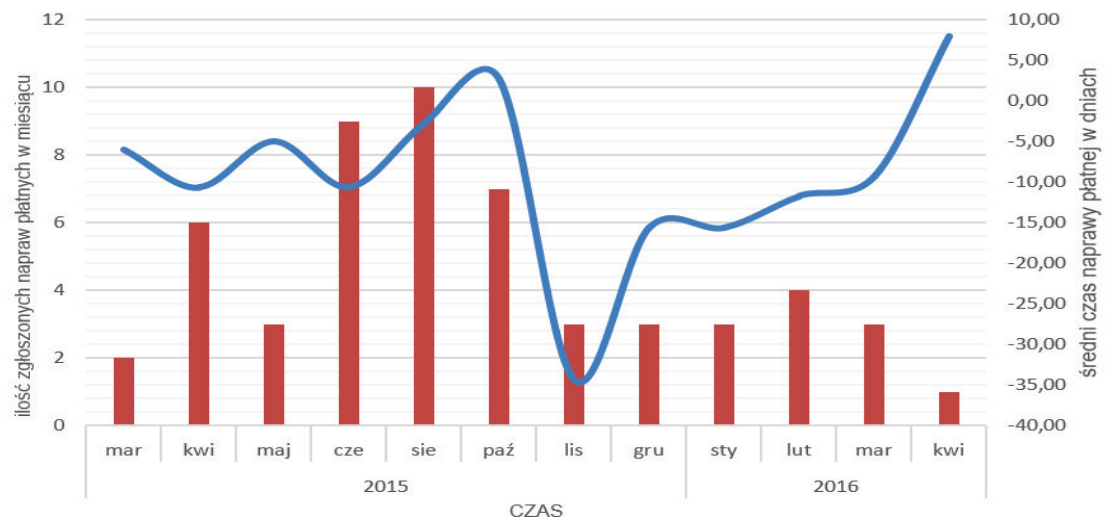

Rys. 6. Liczba zgłoszonych uszkodzeń i średni czas naprawy wykonanej odpłatnie

Wszystkie wykresy przedstawione poniżej (rys. 7-12) wykonano, wykorzystując podział osi czasu na poszczególne miesiące pracy punktu serwisowego. W analizie rodzaju uszkodzenia uwzględniano tylko dni robocze, w dni świąteczne serwis nie pracowal. W rejestrach uszkodzeń danego ue uwzględniono wszystkie uszkodzenia, które dotyczyły danego urządzenia, a pojawiły się w punkcie serwisowym w przedziale czasu, w którym prowadzono analizę, tj. 15 miesięcy (od lutego 2015 do kwietnia 2016). Wybrany okres obserwacji charakteryzował się największą częstością występowania uszkodzeń. Wynik ten jest związany bezpośrednio z rozpoczęciem sprzedaży ue w sklepach wielkoformatowych.

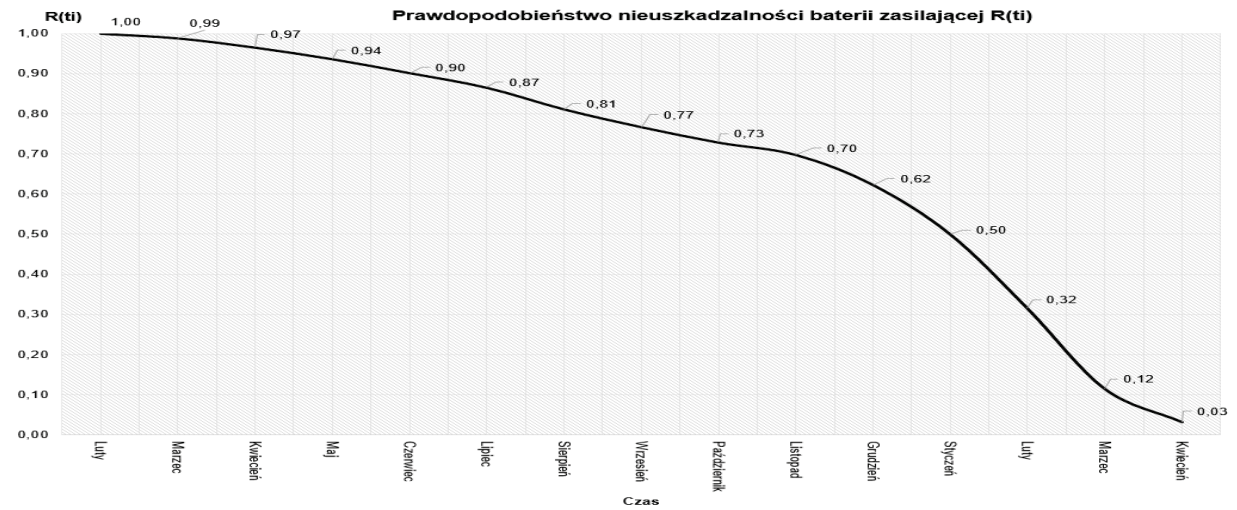

Rys. 7. Prawdopodobieństwo nieuszkadzalności $R\left(t_{i}\right)$ baterii zasilającej 


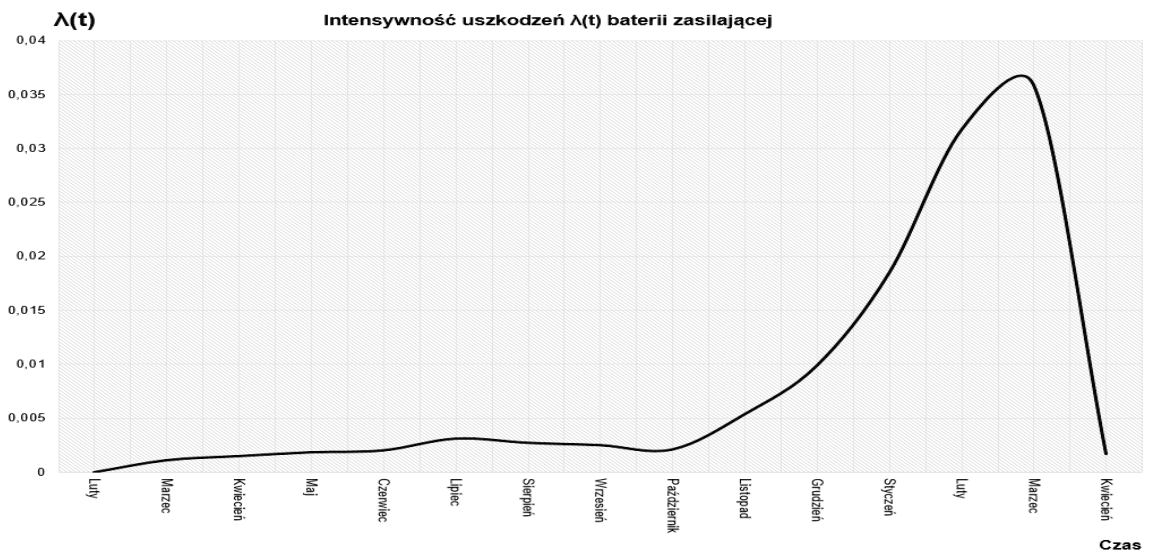

Rys. 8. Intensywność $\lambda(t)$ uszkodzeń baterii zasilającej

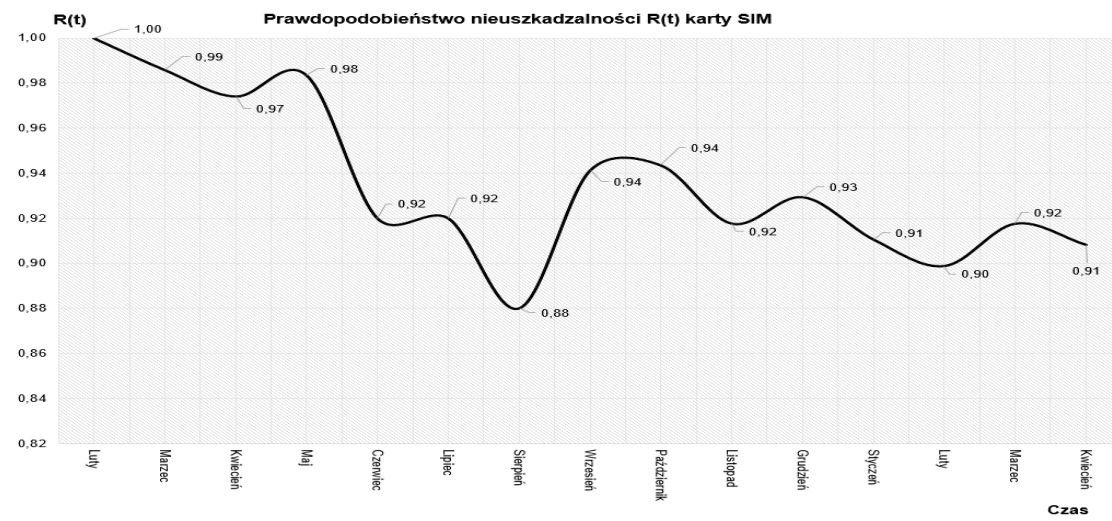

Rys. 9. Prawdopodobieństwo nieuszkadzalności $R(t i)$ karty SIM

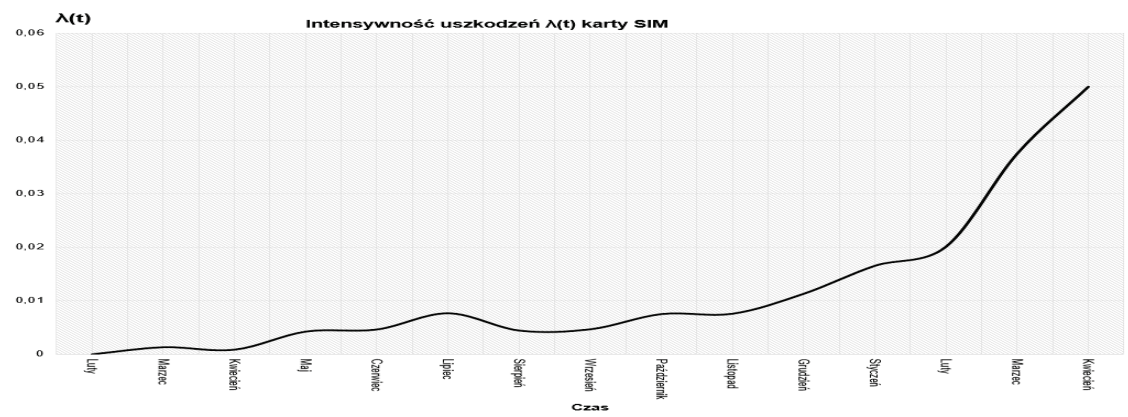

Rys. 10. Intensywność $\lambda(t)$ uszkodzeń karty SIM 


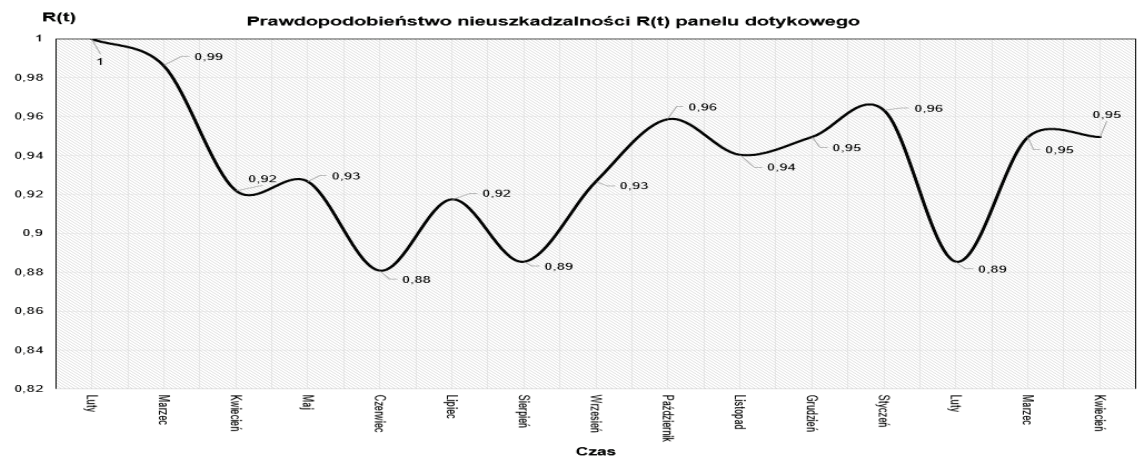

Rys. 11. Prawdopodobieństwo nieuszkadzalności $R(t i)$ panelu dotykowego

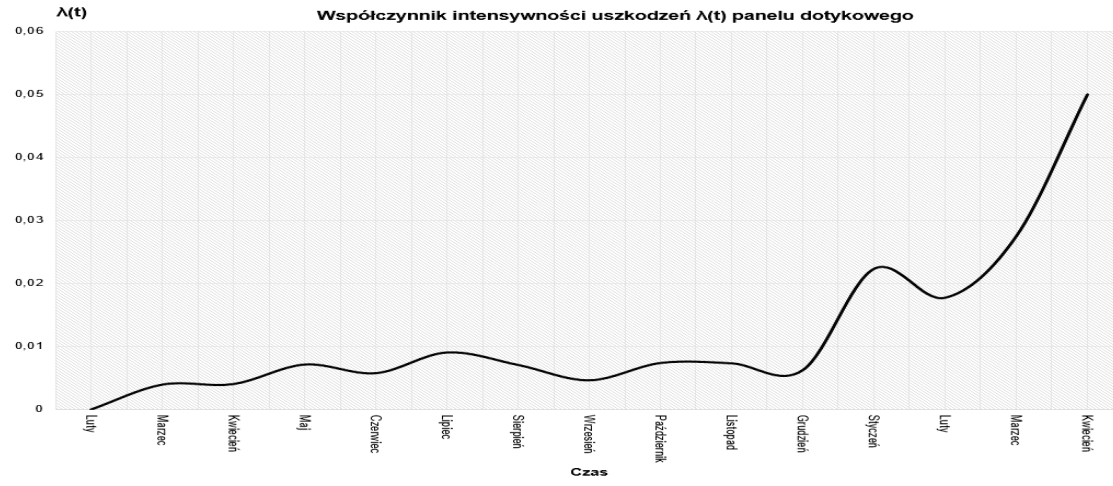

Rys. 12. Intensywność $\lambda(t)$ uszkodzeń panelu dotykowego

\section{Wnioski}

Intensywność uszkodzeń poszczególnych elementów składowych urządzenia elektronicznego jest różna. Największa intensywność uszkodzeń dla baterii zasilających wystąpiła w miesiącach luty - marzec. Są to miesiące zimowe, kiedy temperatury panujące na zewnątrz i wewnatrz hali magazynowej były mniejsze od obowiązujących do przechowywania tego typu urządzeń. Proces uszkodzeń baterii rozpoczął się już w czasie transportu urządzeń do kraju (transport morski). Dodatkowo występowała mniejsza pojemność baterii niż deklarowana przez producenta. Akumulatory powinny być podładowane zaraz po przyjęciu do magazynu. Ładowania baterii nie wykonano ze względu na ograniczone warunki lokalowe i czas. Klient otrzymywał ue z rozładowaną baterią. Po naładowaniu baterii przez $3 \mathrm{~h}$ urządzenie pracowało ok. pół godziny lub się w ogóle nie 
uruchamiało. Sytuacja uległa znacznej poprawie, gdy serwis rozpoczął wymianę baterii na nowe. Niezdatność karty SIM (komunikat na panelu ue) był spowodowany głównie przez dwa różne uszkodzenia. Nieprawidłowe oznaczenie złącza ue, skutek - niepoprawne umiejscowienie karty SIM. Drugie uszkodzenie było typu software’owego (programowego). Producent zbyt późno zareagował na usterkę oprogramowania, a równocześnie nie było możliwości aktualizacji oprogramowania w firmie $[2,4,5,11,10,15]$. Wada oprogramowania dotyczyła każdego ue. Uszkodzenia panelu dotykowego spowodowane były głównie jego wadliwym wykonaniem. Najczęściej objawiało się to brakiem reakcji na dotyk ekranu. Największy wzrost prawdopodobieństwa uszkadzalności panelu dotykowego zanotowano $\mathrm{w}$ miesiącach letnich (w tym czasie najaktywniej korzystano z tabletu - potrzeba skorzystania z Internetu).

Podsumowując, obsługa serwisowa prowadzona przez personel o wysokich kwalifikacjach oraz dostosowanie systemu logistycznego serwisu do efektywnego wykonania napraw ma kluczowe znaczenie w budowaniu satysfakcji klienta i zaufania pośrednika sprzedaży dzięki sprzedaży towarów w sklepach wielkoformatowych.

\section{Literatura}

1. Będkowski L., Dąbrowski T.: Podstawy eksploatacji, cz. II Podstawy niezawodności eksploatacyjnej. WAT, Warszawa 2006.

2. Burdzik R., Konieczny Ł., Figlus T.: Concept of on-board comfort vibration monitoring system for vehicles. In: J. Mikulski (ed.), Activities of Transport Telematics, TST 2013, Springer, Heidelberg 2013.

3. Dyduch J., Paś, J., Rosiński A.: Basics of maintaining electronic transport systems. Publishing House of Radom University of Technology, Radom 2011.

4. Kaniewski P., Lesnik C., Susek W., Serafin P.: Airborne radar terrain imaging system. In 16th International Radar Symposium (IRS), Dresden 2015.

5. Kołowrocki K., Soszyńska-Budny J.: Reliability and safety of complex technical systems and processes. Springer, London 2011.

6. Laskowski D., Łubkowski P., Pawlak E., Stańczyk P.: Anthropotechnical systems reliability. In: „Safety and Reliability: Methodology and Applications - Proceedings of the European Safety and Reliability Conference ESREL 2014”, eds. Nowakowski T., Młyńczak M., Jodejko-Pietruczuk A., Werbińska-Wojciechowska S., CRC Press/Balkema, London 2015.

7. Lewiński A., Perzyński T., Toruń A.: The analysis of open transmission standards in railway control and management. In Communications in Computer and Information Science, Vol. 329, Springer-Verlag, Berlin-Heidelberg 2012. 
8. Paś J., Dąbrowski T.: Metodyka nauczania diagnozowania systemów bezpieczeństwa na przykładzie systemów sygnalizacji włamania i pożaru. Diagnostyka, PTDT, Nr 2(46)/ 2008.

9. Paś J., Rosiński A.: Selected issues regarding the reliability-operational assessment of electronic transport systems with regard to electromagnetic interference. Eksploatacja i Niezawodność - Maintenance and Reliability, Vol. 19, No. 3, 2017 I, DOI 10.17531/ein.2017.3.8.

10. Paś J.: Analysis of exploitation access control system selected object. Przegląd Elektrotechniczny, No. 10, 2015.

11. Paś J.: Operation of electronic transportation systems. Publishing House University of Technology and Humanities, Radom 2015.

12. Paś J.: Selected methods for increases reliability the of electronic systems security, Journal of KONBiN, 3(35), 2015, DOI 10.1515/jok-2015-047.

13. Paszkowski S.: Podstawy teorii systemów i analizy systemowej. WAT, Warszawa 2002.

14. Rosiński A.: Modelowanie procesu eksploatacji systemów telematyki transportu. Oficyna Wydawnicza Politechniki Warszawskiej, Warszawa 2015.

15. Siergiejczyk M., Paś J., Rosiński A.: Issue of reliability-exploitation evaluation of electronic transport systems used in the railway environment with consideration of electromagnetic interference. IET Intelligent Transport Systems, Vol. 10, Iss. 9, November 2016, DOI 10.1049/iet-its.2015.0183.

16. Siergiejczyk M., Paś J., Rosiński A.: Train call recorder and electromagnetic interference. Diagnostyka, Vol. 16, No. 1, 2015.

17. Siergiejczyk M., Rosiński A., Paś J.: Analysis of unintended electromagnetic fields generated by safety system control panels. Diagnostyka, Vol. 17, No. 3, 2016.

18. Żółtowski B.: Reliability engineering guide. ATR, Bydgoszcz 2002. 